\title{
ВЛАДИМИР МИТРОВИЋ
}

Музеј савремене уметности Војводине, Нови Сад

DOI 10.5937/kultura1859154M

УДК 725.822.012(497.113)"1928/1929"

72.071.1 Добровић $\mathrm{H}$.

оригиналан научни рад

\section{HИКОЛА ДОБРОВИЋ: КОНКУРС ЗА ПОЗОРИШТЕУ HOBOM CALУУ И3 1928-1929, TOLИHE}

Сажетак: Током међуратног периода у Новом Саду, као и у другим градовима тадашње земље, била је уобичајена пракса расписивања јавних конкурса за објекте за које је проиењено да имају одређену вредност не само за своје будуће кориснике већ и за нешто што би могли назвати укупном архитектонском естетиком једног града. По пројектном задатку био је то конкурс за подизање нове зграде Српског народног позоришта (СНП), одржаног крајем 1928. и током прве половине 1929. године. На конкурсу је учествовао велики број домаћих архитеката из читаве земље, као и неколико архитеката који су живели у инострантву, какав је случај и са Николом Добровићем, тада настањеним у Прагу. Фактички конкурс на крају није успео а од изградње нове позоришне зграде убрзо се сасвим одустало. Ипак остали су сачувани опис и коментари Косте Страјнића, као и изглед неколико архитектонских пројеката који су били оцењени као успели. На првом месту је конкурсни рад архитекте Николе Добровића који је и поред несумњивог квалитета и најбољег пласмана, у круговима који су одлучивали, означен као „,недовољно модеран за новосадску средину”. Локација на којој је била предвиђена изградюа позоришта убрзо је постала својеврсна раскрсница на којој су изграђени данас већ класични примери модерне српске архитектуре. Тако је, различитим сплетом историјских околности, Нови Сад остао не само без нове зграде за Српско народно позориште већ и без дела архитекте Николе Добровића, великана српске модернистичке архитектуре.

Кључне речи: Добровић, Нови Сад, позориште, конкурс, исход 


\section{ВЛАДИМИР МИТРОВИЋ}

Архитектонска каријера Николе Добровића у досадашњој историографији већ је дефинисана по градовима и периодима у којима је стварао - Прашки (1923-1934), Дубровачки (1934-1943) и Београдски (1945-1967). Студије архитектуре Добровић је започео у Будимпешти (1915), а након прекида због Првог светског рата, наставио их је на Одсеку за архитектуру Високе школе за архитектуру и грађевину на Чешком техничком универзитету у Прагу, где је дипломирао 1923. године. По окончању студија, Добровић борави неколико месеци у Београду безуспешно тражећи ангажман. Посредством својих прашких професора Добровић по повратку у Праг професионалну каријеру започиње прво у атељеу Бохуслава Хипшмана (1923-1925) да би потом кратко радио у атељеу професора др Антонина Енгела. Од 1925. године Добровић као архитекта делује у познатом градитељском бироу „Душек - Козак - Маца”, које је у то време једно од највећих и најзапосленијих предузећа у Прагу. Од 1929. године до повратка у земљу 1934, деловао је као слободан уметник, преузимајући самостално радове. Љиљана Бабић у тексту публикованом у часопису Архитектура урбанизам поводом Добровићеве смрти, детаљно говори о његовим прашким почецима, са пуно детаља који очигледно потичу из разговора са архитектом. ${ }^{1}$ Тања Дамљановић у значајној мери допуњава дотадашње податке о Добровићевом прашком периоду, откривајући и неке његове нове објекте настале у чехословачкој престоници, у сарадњи са арх. Бохумиром Козаком, или самостално. ${ }^{2}$ И други истраживачи Добровићевог рада подвлаче улогу његових прашких година. ${ }^{3}$

Сликар Петар Добровић у својим интервјуима и писмима, мада индиректно, помиње Николин рад до 1930. године где припада и конкурс за новосадско позорише. У једном разговору са Мирославом Крлежом, објављеном у загребачком часопису Савременик (октобар/децембар 1931), Петар каже: „Мога брата Николу прогласили су у Београду кубистом и

1 Babić, L. (1967) Arhitekta Nikola Dobrović, Arhitektura urbanizam br. 43, Beograd, str. 24.

2 Дамљановић, Т. (1995/96) Прилог проучавању прашког периода Николе Добровића, Саопштеља XXVII-XXVIII, Београд: Републички завод за заштиту споменика културе, стр. 237-251.

3 Krstić, D. (1969) Prilog biografiji arh. Nikole Dobrovića - konkurs za novosadsko pozorište, Arhitektura urbanizam br. 56-57, Beograd: str. 28-29; Manević, Z. (1981) Naši neimari: Nikola Dobrović, Izgradnja 1, Beograd, str. 45-51; Vukotić Lazar, M. (2002) Beogradsko razdoblje Nikole Dobrovića (1945-1967), Beograd: Plato, str. 25-42; Blagojević, L. (2003) Modernism in Serbia: the elusive margins of Belgrade architecture 1919-1941, Cambridge, Massachusetts: The MIT Press, pg. 104-117; Маневић, 3. (2008) Добровић Никола, Лексикон неимара, Београд: Грађевинска књига, стр. 100-104. 
чешким имитатором, а у Холандији су за њега утврдили да је у сваком погледу оригиналан и самоникли таленат”. Такође, у једном писму упућеном Милану Кашанину (21. марта 1930) помиње да је недавно случајно упознао највећег теоретичара савремене архитектуре Холанђанина Теа ван Доесбоурга, „као познаваоца и великог пријатеља радова мога брата, кога лично и не познаје". ${ }^{4}$

Београд је 1929. године чуо за име Николе Добровића као добитника међународне награде за Теразијску терасу. Било је то ново име за југословенску јавност, име младог архитекте који шаље свој конкурсни рад из Прага. То је уједно и први директни додир Београда са модерном архитектуром. Пројекат је био последња реч архитектуре тога времена, чешка рецензија модерне архитектуре. ${ }^{5}$ Ове Минићеве речи би се могле применити и на конкурсни рад за Новосадско позориште, уз додатак да домаћа средина, посебно мала каква је био Нови Сад тога доба, једноставно није могао прихватити такву количину модерне архитектуре. Једном речју, Добровићеви прашки конкурсни радови за Нови Сад и Београд били су сувише смели и сувише модерни за домаћу средину још ненавикнуту на савремена стремљења у архитектури. Исто важи и за конкурс за Купалиште Бачвище у Сплиту (1930). У ствари, сукоб српске средине и Николе Добровића, као ортодоксног модернисте европског образовања, био је дубок и суштински. Упркос романтичној бујности, широким захватима и снажним сукобима кубичних маса, Добровићев модернизам био је исувише европски обојен, исувише анационалан за ондашњу српску средину. ${ }^{6}$

Добровићев конкурсни рад за Новосадско позориште настао је вероватно у периоду јануар - фебруар 1929. године, као и конкурс за Теразијску терасу, на коме ради неколико месеци касније. Ова два његова конкурсна рада стога се могу с правом сматрати делом његовог прашког периода не само због чињенице да су тамо настали већ и због очигледног утицаја и архитектонских околности у тадашњој савременој архитектури Чехословачке и посебно Прага. Нема сумње да је конкурс за Новосадско позориште био један од првих наступа модерне архитектуре у домаћој средини и да је самом Добровићу био веома важан те да је био посебно заинтересован

4 Документаичја о стваралаштву Петра Добровића 3. Ликовне критике, интервјуи, политички чланци, писма (приредила Олга Добровић), (2002), Нови Сад: Галерија Матице српске, стр. 81, 150.

5 Minić, O. (1967) Dobrović - život posvećen arhitekturi, Arhitektura urbanizam 43, Beograd, str. 36.

6 Маневић, 3. (1972) Српска архитектура 1900-1970, Београд: Музеј савремене уметности, стр. 23-24. 


\section{ВЛАДИМИР МИТРОВИЋ}

за његово остварење. Свакако не треба занемарити и његове чврсте породичне везе са Новим Садом. ${ }^{7}$ Конкурсни рад за позориште у Новом Саду објављиван је комплетно или делимично у више наврата. ${ }^{8}$ Исти рад Добровић је (вероватно) излагао на својим заједничким изложбама са братом Петром у Београду (1930) у Хагу, Ротердаму и Новом Саду (1931) и Прагу (1932). ${ }^{9}$

О организовању и току конкурса за позориште у Новом Саду постоји монографски текст. ${ }^{10}$ У њему су, између осталог, детаљно и на основу архивских докумената из Историјсоког архива Новог Сада, описане припреме за конкурс, локација предвиђена за будућу позоришну зграду, састав конкурсне комисије и учесници, као и разултати а потом одјеци и реаговања стручне и широке јавности.

На конкурс је пристигло 39 радова до краја рока за предају (5. март 1929) који су током априла били представљени јавности у згради Матице српске на главном градском тргу. Разултате конкурсне утакмице објавила је новосадска

7 Добровићева супруга Иванка Добровић (1920-1995) потиче из познате новосадске породице грчког порекла др Косте Хаџи. Њена старија сестра, Олга Добровић (1903-1995), била је удата за Николиног брата, сликара Петра Добровића, који је на неколико слика овековечио њихов породични дом на новосадској Подбари. Супружници, две сестре и два брата, повремено су боравили у тој кући са двориштем препуним зеленила. О породици Хаџи детаљније: Попов, Д. (1996) Најстарији, старији, млађи, најмлађи Коста Хаџи, Свеске за историју Новог Сада бр. 7, Нови Сад: Новосадски клуб и „Прометеј”, стр. 19-32.

8 Страјнић, К. (1929) За савремену архитектуру - поводом конкурса за Новосадско позориште, Летопис Матице српске, књ. 32, св. 3, Нови Сад: Матица српска, стр. 400-403; Dobrović, N. (1931) Konkursni radovi za pozorišnu zgradu u Novom Sadu, Arhitektura br. 3, Ljubljana: str. 76-78; Dobrović, N. (1971) Savremena arhitektura 5, Beograd: Zavod za izdavanje udžbenika, str. 183; Krstić, D. nav. delo, str. 28-29; Popović, Ž. (1986) Istorija arhitekture pozorišta, kazališta, gledališča i teatra Evrope i Jugoslavije, Beograd: Građevinski fakultet, str. 483; Vukotić Lazar, M. nav. delo, str. 35; Mitrović, V. (2010) Arhitektura XX veka u Vojvodini, Novi Sad: Muzej savremene umetnosti Vojvodine, Akademska knjiga, str. 148.

9 Hakman, S. (1930) Zajednička izložba P. Dobrovića, R. Stijovića, N. Dobrovića, Misao sv. 7-8, Zagreb, str. 495-498; Anonim, (1931) Uspjeh Petra Dobrovića slikara i Nikole Dobrovića arhitekte u Holandiji, Savremenik 16-18, Zagreb, str. 299-300; Т. Е. (24. Мај 1931) Изложба слика г. Петра Добровића и архитектонских пројеката г. Николе Добровића у Ротердаму, Време, стр. 7; Аноним, (2. март 1932) Изложбе браће Добровић у Прагу, Време, стр. 2; М. Ј. (2. март 1932) Добровићи излажу у Прагу, Политика, стр. 10.

10 Митровић, В. (1994) Конкурс за градњу позоришта у Новом Саду из 1928/29. године, Рад Музеја Војводине св. 36, Нови Сад: Музеј Војводине, стр. 209-218. Текст је прештампан са мањим корекцијама у: Iz istorije kulture i arhitekture: Zapisi jednog istraživača (1994-2014), Mitrović, V. (2016), Novi Sad: Muzej savremene umetnosti Vojvodine, str. 13-20. 


\section{ВЛАДИМИР МИТРОВИЋ}

Застава. ${ }^{11}$ Оцењивачки одбор, у коме је супротно препорукама Југословенског удружења инжењера и архитеката, био сам један архитекта, Драгиша Брашован, који је и сам узео учешће у конкурсној утакмици, донео одлуку да се прва награда не додели. Другу награду је освојио новосадски архитекта Лазар Дунђерски („Режисер”), трећу хрватски архитекта Алфред Албини (,Дунав - Осијек”), док је откупљено чак пет радова - Николе Добровића („Број 9”), Ђорђа Табаковића („Нови Сад”), Гојка Тодића („Дубравка”), Еде Миклош-Штајнера („Нада”) и браће Бранка и Петра Крстића („Thaleia”).

Најквалитетнији опис свог конкурсног рада дао је сам Добровић у тексту објављеном у љубљанској Архитектури. „Позоришна зграда заузима хоризонтално тачно место према регулационом плану Новог Сада. Само је најближа околина уређена, како то изискују улази и излази у гледалиште, у манипулационе просторије саме позорнице и у административни део са глумачким домом. Вертикално је висина приземља установијена на коту 79.00 због близине подземне воде, а ни најнижи делови зграде не превазилазе коту 75.50. Ради штедње одређен је место масивних зидова систем стубова. Унутрашњи распоред зграде састоји се из три главна дела:

А) Гледалиште. Главни улаз, компонован са стране улице Краљице Марије, може са својим димензијама пропустити и већи број посетилаца ођеданпут. Иза просторног вестибула још просторнија хала смањива својим централним положајем број узиданих кубних метара. Око ње централно су смештене гардеробе. Даље везује она сва степеништа и за спратове довољно димензоване просторије са клозетима. Гледалиште је комбинација амфитеатра и гледалишта са редовима (Rang-theater). Амфитеатрални партер са својих 448 места за седење омогућује свакому гледаоцу удобну позицију. Осим хале за освежавање служи још и променоар са зимском баштом и балконом, који је одређен и за свечаности. Први ред (Rang) је са 180 места и 10 затворених ложа за 56 особа. Ложе заузимају према позорници само фронтални положај, јер смештене по странама показују доста рђавих особина, као што су: оптички не пружају предности, које би одговарале њиховој цени, преграде међу ложама спречавају поглед, па и сама је позиција тела незгодна. Око овога реда налази се просторан променоар. Други ред, са 336 места, у осталом

11 Аноним, (31. март 1929) За конкурс позоришта пристигло 39 планова, Застава, стр. 8 . 


\section{ВЛАДИМИР МИТРОВИЋ}

сличан првоме, симетрично је раздељен простором за стајање, док су ложе, смештене као у предњем реду, отворене и са ниском баријером.

Б) Позорница. Према постојећим прописима позорница је сасвим одељена од гледалишта. Сама површина за игру, довољно димензована, омогућава ради транспарентног осветљавања, да је приређивање великих сцена, уоквирених округлим хоризонтом (Kupler-horizont) и прозирно. Пролаз испод нивоа позорнице за време игре одржава се ходником испод хоризонта. За што бржу преградњу сцена и уопште манипулацију омогућава се измена појединих слика у хоризонталном правцу помоћу точкова и монтажних спратова. Са доњом позорницом су виши простор за оркестар и инструменте с ормарима у зиду за ноте.

Ц) Гардеробе. Раздељене су на два спрата уз позорницу, засебно за глумице и глумце. Вертикална су веза степеништа. Ходници и гардеробе снабдевене су, ради смештања одела и сл. ормарима у зиду. Кројачке радионице и стоваришта костима налазе се у трећем спрату. Административно одељење и дом глумаца заузима задњи део зграде. У приземљу, иза споредног улаза налази се стан вратара. У осталом делу смештене су канцеларије економско-административног вођства. За пробе предвиђена је нарочита сала. Даље је уређена књижница и сала за студирање, а за разоноду служе тераса и балкони." 12

Из једног документа Историјског архива Новог Сада сазнајемо и коментар жирија на Добровићев рад. Конкурсни рад под геслом „,9', стоји у документу, решио је питање комуникације добро, степеништа за партер замишљена су амфитеатрални простор у приземљу. Гледалиште има сувише широк просценијум у случају једног салонског комада, када се сведе ,арлекин" на минимум, места са стране су неупотребљива. Седишта на првом спрату са стране сасвим су погрешно постављена у правој линији и немогућа су због визуере; ложе које треба да буду главни део првог спрата су деградиране. Исто се односи и на други спрат, где су ложе сасвим непотребне за ово позориште. Архитектура је модерна, веома слободна и интересантна. Аутор је бину и простор око бине врло добро решио. ${ }^{13}$ Како је у жириу био једини архитекта Драгиша Брашован и један грађевински инжењер из градске управе, Никола Плавшић, наведени овако стручни коментар су могли написати само они. Наравно уз помоћ неког ко је био добро упознат са свим процесима позоришних

12 Добровић, П. (1931), нав. дело, стр. 76-78.

13 IANS-F.150.24894/1936. 
представа, а то је, у овом случају такође члан жирија, Петар Коњовић, тадашњи директор позоришта у Новом Саду. И поред свега наведеног, стоји Страјнићева примедба да је „неразумљиво зашто је жири био састављен од нестручњака и само од једног архитекте, Драгише Брашована. Према томе искључено је да би жири, у коме је био једини стручњак Д. Брашован, могао комплетно и непристрасно судити о пројектима... А како да се у ову компетентност не сумња када се зна да је Савет, када је позвао Д. Брашована да се прими чланства жирија, истовремено поручио и код њега пројекат (под ознаком „Hors concours”). ${ }^{14}$ Посебну љутњу Страјнића, иначе најжешћег критичара ове конкурсне утакмице, изазвао је став жирија да је Добровићев рад представља „одвише модерну и за Нови Сад несавремену архитектуру”.

Коментар жирија о Добровићевим грешкама у решавању техничких проблема ложа и унутрашњих комуникација, и на самог је аутора оставио дубок утисак који се види у његовом писму упућеном из Прага већ 31. маја 1929. године градоначелнику Новог Сада, др Браниславу Бороти, где се, не без дозе гнева, жали на Брашованов поступак и захтева исти третман за себе: „... да би могао показати свеје способности у пуном опсегу, као што је то учинио г. Брашован, да на свој трошак путујем у Нови Сад и да предам лично своје радове, као што је био учинио г. Брашован и да образложим своје планове члановима оцењивачког одбора колико год то буде требало, као што је био учинио и г. Брашован". Даље Добровић скоро љутито коментарише градоначелникову изјаву дневним новинама на мађарском језику које су у то време биле штампане у Суботици. 'У ствари Вашег мишљења о мом пројекту обелодањеном у Bacsmegyei Naplo, да он садржава такве елементарне грешке и да (je) због тога морао при додељивању награда да испадне из комбинације, слободан сам упозорити Вас, да сте се изволили пренаглити. Критичар сам и сувише хладан, тако да могу не само одредити са сигурношћу каквом је нивоу мој пројекат у европској релацији, него и установити са лакоћом, колико може један нестручњак, макар би он и градоначелник био, да се разуме у техничке знаности. Због тога не сматрам Вашу изреку за увредљиву, али изволите и другима омогућити, да се својом радиношћу и пожртвованошћу пониште извесне предрасуде, које у себи гајите и да покажу на оно уско и једнострано становиште са којег полазите, не само у расписивању конкурса, мењању услова и оцењивачког одбора и одређењу рокова него и у самом поверивању градње"”.

14 Страјнић, К. нав. дело стр. 401. 


\section{ВЛАДИМИР МИТРОВИЋ}

Да је Добровићу овај конкурсни пројекат био изузетно важан потврђује и друго писмо, интонирано у знатно блажем и умеренијем тону, такође упућено новосадском градоначелнику, овога пута из самог Новог Сада 26. новембра 1930. године, у коме аутор износи конкретну понуду: „... Ако град Нови Сад пристине да се позориште подигне према плановима које сам ја пројектовао и ако се мени повери извођење градње, ја ћу, пошто ми стоји на расположењу једна јака финансијска група чешких финансијера из Прага, ставити сав за изградњу позоришта потребан капитал у износу од око 11 милиона динара на расположење. Обавезујем се извршити градњу строго према пројекту од најбољег материјала. Према томе, молим Вас г. Градоначелниче, да овај мој предлог изволите саопштити градском Савету, пре свега ради принципијелнога прихвата, па ако Градски Савет у начелу прихвати овај предлог и о томе мене путем мога опуномоћеника адвоката др Косте Хаџи извести, поднећу Вама и Градском Савету и план за амортизацију уложеног капитала као и услове за обезбеђење амортизационих рата о чему ће имати Градски Савет посебну одлуку донети." 15 Како видимо, Добровићев предлог се односио не само на понуду свог пројекта и рада на извођењу већ и на неку врсту финансијске конструкције за обезбеђивање самих средстава за изградњу. Предлог је одбијен са образложењем да би Град био везан у погледу избора нацрта и избора извођача саме градње.

Током наредних пар година идеја али и конкретна акција око подизања нове позоришне зграде полако је губила свој првобитни ентузијазам и фактички се полако гасила. Када je 1. децембра 1936. године отворена нова зграда Соколског дома, подигнута по пројектима арх. Ђорђа Табаковића, који је предвиђао и за то време пристојно уређењу и дефинисану позоришну салу, коначно се одустало од изградње наменске позоришне зграде. Током наредног периода све активности позоришта у Новом Саду одвијале су се у Соколском дому као и у времену после Другог светског рата, када се у згради, поред представа, сада већ Српског народног позоришта, одржавало и Стеријино позорје (од 1956), као највећа манифестација југословенске позоришне уметности.

Непосредна околина локације предвиђене за изградњу позоришта током четврте деценије је постала својеврсна поставка на отвореном са данас већ класичним примерима модерних дела српских архитеката - Драгиша Брашован, Милан Секулић, Ђорђе Табаковић, Данило Каћански и Бранислав

15 Оба Добровићева писма се чувају у Историјском архиву Новог Сада: IANS-F.150. 35692/1929. 


\section{ВЛАДИМИР МИТРОВИЋ}

Ристић. Различитим сплетом историјских околности, Нови Сад је остао не само без нове зграде за Српско народно позориште већ и без дела архитекте Николе Добровића, великана српске модернистичке архитектуре. Тако је конкурс за новосадско позориште из 1928/29. године, као вероватно једна од у домаћој историографији највише коментарисаних, публикованих и анализираних манифестација ове врсте архитектонског стваралаштва у међуратној Краљевини Југославији, остало, нажалост, без конкретног резултата.

\section{ЛИТЕРАТУРА:}

Аноним, (31. март 1929) За конкурс позоришта пристигло 39 планова, Застава, стр. 8.

Anonim, (1931) Uspjeh Petra Dobrovića slikara i Nikole Dobrovića arhitekte u Holandiji, Savremenik 16-18, Zagreb: str. 299-300.

Аноним, (2. март 1932) Изложбе браће Добровић у Прагу, Време, стр. 2.

Babić, L. (1967) Arhitekta Nikola Dobrović, Arhitektura urbanizam br. 43, Beograd, str. 22-31.

Blagojević, L. (2003) Modernism in Serbia: the elusive margins of Belgrade architecture 1919-1941, Cambridge, Massachusetts: The MIT Press, pg. 104-117.

Vukotić Lazar, M. (2002) Beogradsko razdoblje Nikole Dobrovića (1945-1967), Beograd: Plato, str. 35, 37-38.

Дамљановић, Т. (1995/96) Прилог проучавању прашког периода Николе Добровића, Саопштења XXVII-XXVIII, Београд:

Републички завод за заштиту споменика културе, стр. 237-251.

Dobrović, N. (1931) Konkursni radovi za pozorišnu zgradu u Novom Sadu, Arhitektura br. 3, Ljubljana: str. 76-78.

Dobrović, N. (1971) Savremena arhitektura 5, Beograd: Zavod za izdavanje udžbenika.

Документаиија о стваралаштву Петра Добровића 3. Ликовне критике, интервјуи, политички чланци, писма, (приредила Олга Добровић), (2002), Нови Сад: Галерија Матице српске, стр. 81, 150.

Krstić, D. (1969) Prilog biografiji arh. Nikole Dobrovića - konkurs za novosadsko pozorište, Arhitektura urbanizam br. 56-57, Beograd: str. $28-29$.

М. J. (2. март 1932) Добровићи излажу у Прагу, Политика, стр. 10.

Маневић, 3. (1972) Српска архитектура 1900-1970, Београд: Музеј савремене уметности, стр. 23-24.

Manević, Z. (1981) Naši neimari: Nikola Dobrović, Izgradnja 1, Beograd, str. 45-51. 


\section{ВЛАДИМИР МИТРОВИЋ}

Маневић, 3. (2008) Добровић Никола, Лексикон неимара, Београд: Грађевинска књига, стр. 100-104.

Macura, M. (1967) Ličnost Nikole Dobrovića, Arhitektura urbanizam 43, Beograd.

Minić, O. (1967) Dobrović - život posvećen arhitekturi, Arhitektura urbanizam 43, Beograd, str. 36-37.

Митровић, В. (1994) Конкурс за градњу позоришта у Новом Саду из 1928/29. године, Рад Музеја Војводине св. 36, Нови Сад: Музеј Војводине, стр. 209-218.

Mitrović, V. (2010) Arhitektura XX veka u Vojvodini, Novi Sad: Muzej savremene umetnosti Vojvodine, Akademska knjiga, str. 148-149.

Mitrović, V. (2016) Iz istorije kulture i arhitekture: Zapisi jednog istraživača (1994-2014), Novi Sad: Muzej savremene umetnosti Vojvodine, str. 13-20.

Perović, M. Krunić, Spasoje. (Urednici), (1998) Nikola Dobrović: Eseji, projekti, kritike, Beograd: Arhitektonski fakultet, Muzej Nauke i tehnike, Muzej arhitekture

Petričić, B. (1967) Sećanje na arhitektu Nikolu Dobrovića, Arhitektura urbanizam 43, Beograd.

Попов, Д. (1996) Најстарији, старији, млађи, најмлађи Коста Хаџи, Свеске за историју Новог Сада бр. 7, Нови Сад: Новосадски клуб, „Прометеј”, стр. 19-32.

Popović, Ž. (1986) Istorija arhitekture pozorišta, kazallišta, gledališča i teatra Evrope i Jugoslavije, Beograd: Građevinski fakultet, str. 481-483.

Страјнић, К. (1929) За савремену архитектуру - поводом конкурса за Новосадско позориште, Летопис Матице српске, књ. 32, св. 3, Нови Сад: Матица српска, стр. 400-403.

Т. Е. (24. Мај 1931) Изложба слика г. Петра Добровића и архитектонских пројеката г. Николе Добровића у Ротердаму, Време.

Hakman, S. (1930) Zajednička izložba P. Dobrovića, R. Stijovića, N. Dobrovića, Misao sv. 7-8, Zagreb, str. 495-498. 


\section{ВЛАДИМИР МИТРОВИЋ}

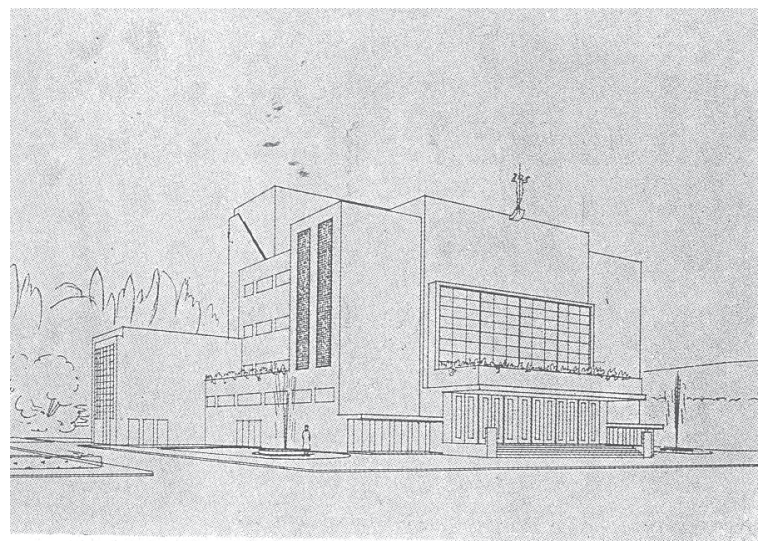

Прилог 1 Главни поглед на позоришну зграду у Новом Саду; Извор: Dobrović, N. (1931), str. 76-77.

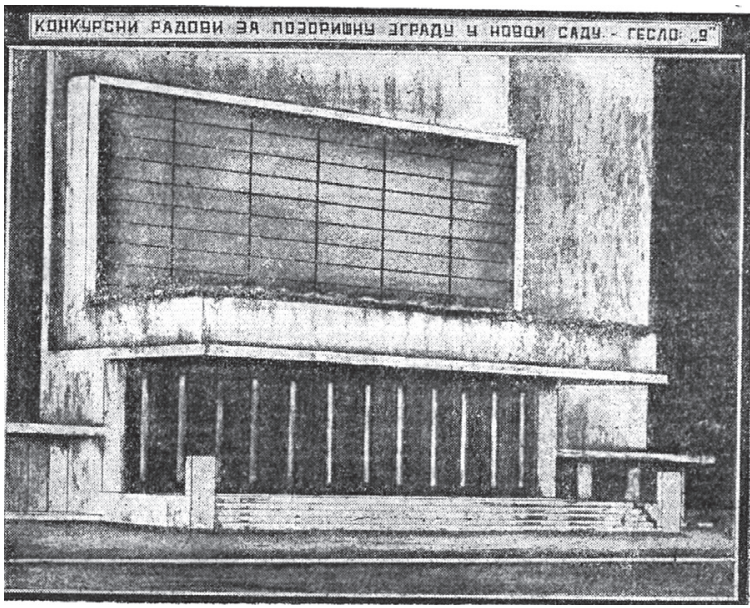

Прилог 2 Главни улаз;

Извор: Dobrović, N. (1971), str. 183.

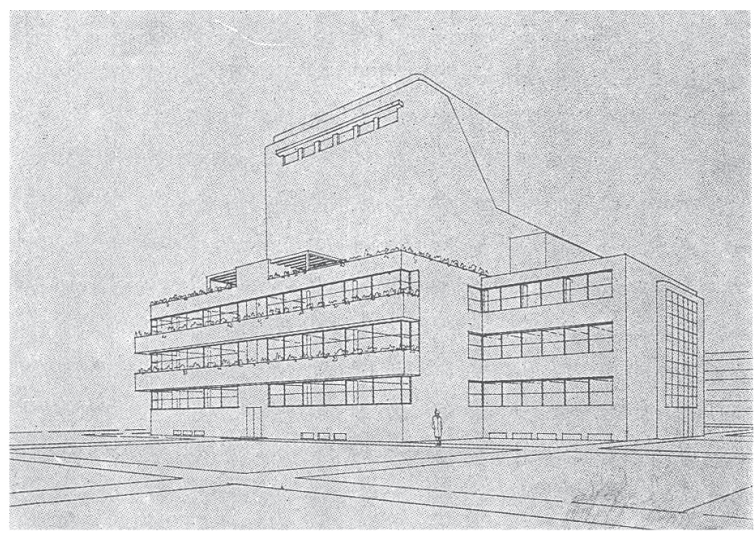

Прилог 3 Поглед са стране;

Извор: Dobrović, N. (1931), str. 76-77. 


\section{ВЛАДИМИР МИТРОВИЋ}

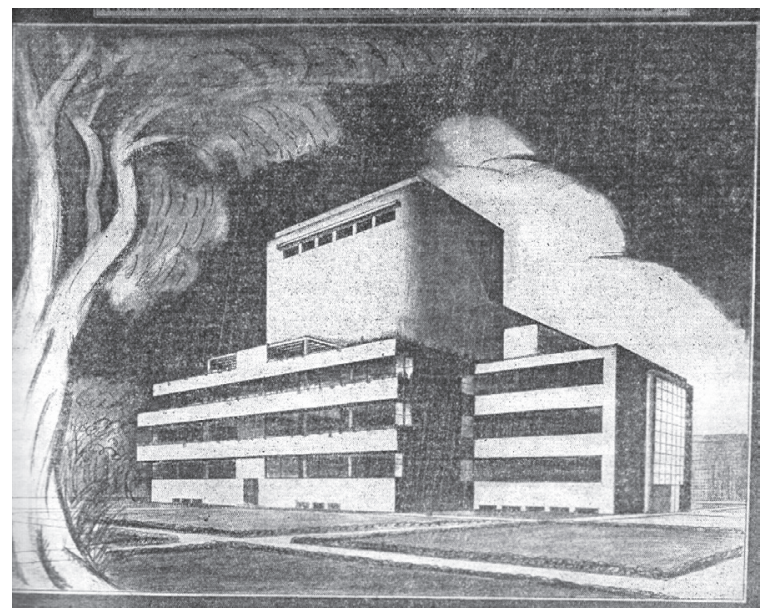

Прилог 4 Перспективни изглед;

Извор: Dobrović, N. (1971), str. 183.

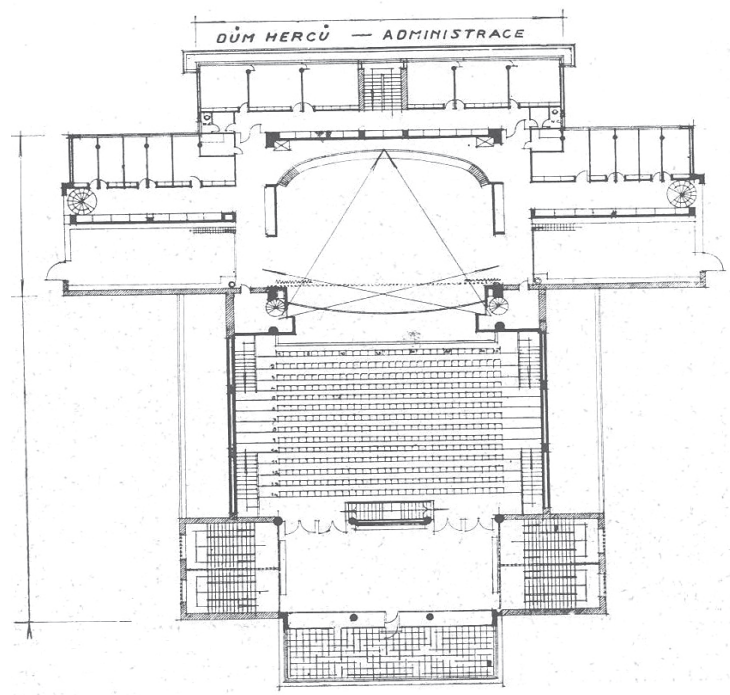

Прилог 5 Тлоцрт приземља;

Извор: Dobrović, N. (1931), str. 76-77. 


\title{
ВЛАДИМИР МИТРОВИЋ
}

\author{
Vladimir Mitrović \\ Museum of Contemporary Art of Vojvodina, Novi Sad \\ NIKOLA DOBROVIĆ: OPEN BUILDING DESIGN \\ COMPETITION FROM 1928/29 FOR THE THEATRE IN \\ NOVI SAD
}

\begin{abstract}
In between the two World Wars, it was practice in Novi Sad, and in other cities across the country, to have open calls for the design of facilities which were deemed of certain value not just to their immediate users, but also to something we could call the overall architectural aesthetics of a city. One of them was the open competition with terms of reference for a new building of the Serbian National Theatre (SNP), which was launched at the end of 1928 and remained open for the first half of 1929. A large number of architects from over the country applied, including some who lived abroad, like Nikola Dobrović who happened to live in Prague at the time. The competition never closed properly and the idea of building a new theatre was soon to be abandoned. Still, what has remained is a description and a commentary by Kosta Strajnić, as well as visual evidence of some of the architectural solutions which were evaluated as most successful. The top of the list was a solution by the architect Nikola Dobrović, which in addition to evident quality and the first place in evaluation, was also marked as "insufficiently modern for the Novi Sad environment" by circles that made decisions. The location intended for the theatre soon became a crossroads with many examples of modern Serbian architecture, which are today considered as classic pieces of architecture. Due to an intricate net of historic circumstances, Novi Sad thus remained deprived not only of a new seat of the Serbian National Theatre, but also deprived of a building by a great master of modern Serbian architecture, Nikola Dobrović.
\end{abstract}

Key words: Dobrović, Novi Sad, theatre, competition, result 